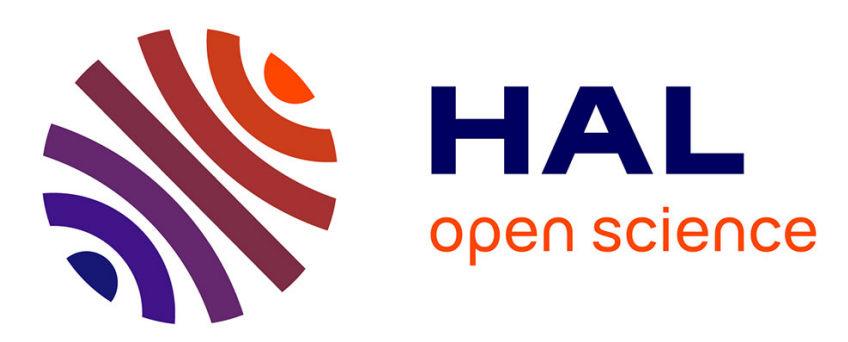

\title{
Testing an area-weighted model for albedo or surface temperature of mixed pixels in Mediterranean woodlands
}

\author{
S. Rambal, B. Lacaze, T. Winkel
}

\section{- To cite this version:}

S. Rambal, B. Lacaze, T. Winkel. Testing an area-weighted model for albedo or surface temperature of mixed pixels in Mediterranean woodlands. International Journal of Remote Sensing, 1989, 11 (8), pp.1495-1499. 10.1080/01431169008955107 . ird-03373361

\section{HAL Id: ird-03373361 https://hal.ird.fr/ird-03373361}

Submitted on 11 Oct 2021

HAL is a multi-disciplinary open access archive for the deposit and dissemination of scientific research documents, whether they are published or not. The documents may come from teaching and research institutions in France or abroad, or from public or private research centers.
L'archive ouverte pluridisciplinaire HAL, est destinée au dépôt et à la diffusion de documents scientifiques de niveau recherche, publiés ou non, émanant des établissements d'enseignement et de recherche français ou étrangers, des laboratoires publics ou privés. 
INT. J. REMOTE SENSING, 1990, VOL 11, NO. 8, 1495-1499

\title{
Testing an area-weighted model for albedo or surface temperature of mixed pixels in Mediterranean woodlands
}

\author{
S. RAMBAL, B. LACAZE, and T. WINKEL \\ Centre L. Emberger, CNRS, B.P. 5051, 34033, Montpellier Cedex, France
}

(Received 23 June 1989, in final form 7 December 1989)

\begin{abstract}
We have tested the following assumption for a spatially complex area of natural vegetation in Southern France. The spectral response of a mixed pixel is a linear combination of the individual responses of its components. The test has been done with HCMM data; each pixel ( $500 \mathrm{~m}$ spatial resolution) has been characterized by its components defined as physiognomical vegetation units. Results from the analysis of multitemporal HCMM data indicate that the assumption is verified for albedos and surface temperatures.
\end{abstract}

\section{Introduction}

The increasing interest in global monitoring of vegetation has emphasized the need for instruments imaging the whole globe with high temporal resolution. Consequently, spatial resolution of sensors must be limited because of resultant data volume. At the present time, many studies are based on NOAA /Advanced Very High Resolution Radiometer (AVHRR) data, with $1 \cdot 1 \mathrm{~km}$ spatial resolution at best, and global data sets are available only in a sampled, spatially-degraded form. In future systems, an efficient monitoring of landscape changes may require a spatial resolution finer than $1.1 \mathrm{~km}$. However, a compromise should still be established between spectral, spatial and temporal resolutions. Townshend and Justice (1988), with reference to the proposed Moderate Resolution Imaging Spectrometer, MODIS (Salomonson et al. 1989), claim that a sensor with a resolution of $500 \mathrm{~m}$ should provide the best compromise between detail of changes detected and size of data volume. Considering this resolution of $500 \mathrm{~m}$, most pixels in the imagery will be mixed pixels, as the corresponding ground patch areas will include several land cover types.

What is the significance of physical parameters measured over composite areas? The linear hypothesis has been generally proposed for albedo. For example, the reflectance of a crop is modelled as a linear combination of reflectances of vegetation and bare soil (Badhwar 1980). The same linear hypothesis has been proposed at a global scale, with the objective of predicting climatic changes associated with variations of the Earth's albedo (Sagan et al. 1979).

Concerning surface temperature, Garratt (1978) has made a comparison between airborne measurements over mixed pixels and ground measurements of their components: bare soil, herbaceous vegetation and trees. He suggested that the spatiallyaveraged latent heat flux be considered as the sum of the contributions of each component. He came to the conclusion that the process generating the surface temperature of a composite area when dealing with high contrasts in the roughness of the components was nonlinear (see also Ross et al. 1985, Kustas et al. 1989). Byrne et al. (1979) calculated the apparent temperature of a bare soil with bushes from the long wave flux per unit area, applying the Stefan-Boltzmann law for each

$$
\begin{aligned}
& \text { 0143-1161/90 \$3.00 } 1990 \text { Taylor \& Francis } \text { U.R.S.T.O.M. Fonds Documentaife } \\
& N^{\circ}: 43678 \\
& \text { Cote: } B \text { exA }
\end{aligned}
$$


individual surface. They concluded that "notwithstanding the fact that the relationship is a fourth-power one. the temperature range involved is small and the departure from linearity is not great".

Considering a spatially complex area of natural vegetation in Southern France, we have tested the simplest assumption: the spectral albedo (or surface temperature) obtained with a $500 \mathrm{~m}$ resolution pixel is equal to the spectral albedo (or surface temperature) of components weighted by their relative areas.

\section{Test area and available data}

The test area is a small watershed $\left(50 \mathrm{~km}^{2}\right)$. located $20 \mathrm{~km}$ north of Montpellier, France, and representative of Mediterranean karst watersheds. It was chosen because of its homogeneous lithologic substratum and the relative flatness of the terrain. The dominant tree species in the area are the evergreen Qu'rcus ile $X$ L. and the deciduous Quercus pubescens Willd.

Thematic data were drawn from a vegetation cover map. established at the scale of 1:50000. Vegetation physiognomy had been assessed quantitatively through a codification based upon the respective projected covers of trees (higher than $2 \mathrm{~m}$ ). shrubs and herbaceous layer. Projected covers of the three layers had been estimated visually in the field, and the boundaries of vegetation units had been delineated from aerial photographs. For the purposes of this study, four simplified vegetation classes, referred to as vegetation formations were used (table 1 ).

Satellite sensor data were obtained from the Heat Capacity Mapping Mission (HCMM) of Explorer 1 satellite (NASA 1980). Spectral radiances in visible/near infrared and thermal infrared wavelengths have been recorded with spatial resolutions of $500 \times 500 \mathrm{~m}$ and $600 \times 600 \mathrm{~m}$ respectively. Five acquisition dates have been considered: 6 May, 4 July, 21 August. 31 August and 27 September 1979. Only diurnal data, obtained close to the daytime maximum. have been taken into account. For each date, data from the two channels have been spatially registered.

\section{Methods}

Albedo values have been derived from the calibration equation published by NASA (1980). To reduce atmospheric variations among the five dates, we adopted at normalization procedure. assigning an albedo value recorded over seawater to $0 \cdot 05$. a value considered as relatively constant in the literature. The derived albedo values. which are more precisely spectral albedos measured in the 0.55 to $1.1 \mu \mathrm{m}$ domain. are comparable to either literature values, other satellite estimates. and ground measurements (Lacaze et al. 1984). In a similar way, surface temperatures have been

Table 1. Definition of the vegetation formations and some of their structural characteristics. Tree cover is expressed in percentage of vertically projected cover. Mean heights are calculated at the cover class marks assuming a tree height of $4 \mathrm{~m}$. Roughness was calculated dividing mean heights by $8 \cdot 15$ (Brutsaert 1982).

\begin{tabular}{lccc}
\hline Vegetation formation & $\begin{array}{c}\text { Tree cover } \\
(\% 0)\end{array}$ & $\begin{array}{c}\text { Mean height } \\
(\mathrm{m})\end{array}$ & $\begin{array}{c}\text { Roughness } \\
(\mathrm{m})\end{array}$ \\
\hline $\begin{array}{l}\text { Dense woodland } \\
\text { Mid-dense woodland }\end{array}$ & $75-100$ & $3 \cdot 5$ & $0 \cdot 43$ \\
Open woodland & $5(1-75$ & $2 \cdot 5$ & $0 \cdot 31$ \\
Shrubland & $25-50$ & $1 \cdot 3$ & $0 \cdot 16$ \\
\hline
\end{tabular}


computed with the calibration equations provided by NASA (1980), including the linear correction proposed by Reiniger (1981).

By superimposing a grid reproducing $\mathrm{HCMM}$ pixels on the vegetation cover map, we could calculate the percentage of each vegetation formation in each pixel. The registration of HCMM data with the vegetation map was adjusted through the consideration of sharp topographic features surrounding the test area.

A general linear model of the form

$$
o=\Sigma_{j} k_{j} a_{j} \text { or } o^{\prime}=\Sigma_{j} k_{j} t_{\mathrm{s} j} \text { where } \Sigma k_{j}=1
$$

is used for each pixel. Where $o$ or $o^{\prime}$ are the independent variables, that is the observed albedo or surface temperature; $k_{j}(j=1,4)$ are independent variables, that is the percentage of the $j^{\text {th }}$ vegetation formation in the considered pixel and $a_{j}$ or $t_{\mathrm{s} j}$ are unknown parameters, that is the albedo or the surface temperature of the $j^{\text {th }}$ vegetation formation. In practice $n$ observations, the number of pixels under study, would be available on $o$ and $o^{\prime}$ with the corresponding $n$ observations on each of the $j$ independent variables. Thus, $n$ equations like equation (1) can be written. Essentially we will be solving $n$ equations for $j=4$ unknown parameters. In matrix notation the equations are:

$$
\mathbf{O}=K A \quad \text { or } \quad \mathbf{O}^{\prime}=K \mathrm{~T}_{\mathrm{s}}
$$

where $\mathbf{O}$ and $\mathbf{O}^{\prime}$ are the $n \times 1$ vectors of observations, $K$ is a $4 \times n$ matrix made up of $n$ observations on each of the four independent variables, and $\mathbf{A}$ or $T_{s}$ are $4 \times 1$ vectors of unknown parameters. These vectors can be estimated by:

$$
\mathbf{A}=\left(K^{\mathrm{T}} K^{-1}\right) K^{\mathrm{T}} \mathbf{O} \quad \text { or } \quad \mathbf{T}_{\mathrm{s}}=\left(K^{\mathrm{T}} K^{-1}\right) K^{\mathrm{T}} \mathbf{O}^{\prime}
$$
197.

The transposed of $K$ is denoted by $K^{\mathrm{T}}$. In this study, the number of pixels $(n)$ is

\section{Results and discussion}

The estimations of albedo and surface temperature of vegetation formations, following equation (3), are reported respectively in tables 2 and 3. The calculated correlation coefficients and $\mathrm{F}$-ratios of the overall regression equations (mean square due to regression divided by the residual mean square) are also given. The tabulated $\mathrm{F}_{0.95}$ is 2.65 . Therefore, all the regression equations explain a significant amount of the variation of $a$ and $t_{\mathrm{s}}$.

Table 2. Albedo estimated by multiple regression for each of the four vegetation formations and the five studied dates. The correlation coefficients and the F-ratios of the overall regression equations are also reported.

\begin{tabular}{llcccc}
\hline & & \multicolumn{4}{c}{ ALBEDO } \\
& 6 May & 4 July & 21 August & 31 August & 27 September \\
\hline Shrubland & $0 \cdot 136$ & $0 \cdot 152$ & $0 \cdot 131$ & $0 \cdot 135$ & $0 \cdot 117$ \\
Open woodland & $0 \cdot 136$ & $0 \cdot 156$ & $0 \cdot 133$ & $0 \cdot 136$ & $0 \cdot 120$ \\
Mid-dense woodland & $0 \cdot 130$ & $0 \cdot 149$ & $0 \cdot 123$ & $0 \cdot 127$ & $0 \cdot 113$ \\
Dense woodland & $0 \cdot 116$ & $0 \cdot 134$ & $0 \cdot 114$ & $0 \cdot 115$ & $0 \cdot 102$ \\
Correlation coefficients & 0.38 & 0.53 & $0 \cdot 65$ & $0 \cdot 69$ & $0 \cdot 61$ \\
$\quad$ F-ratios & $7 \cdot 9$ & $19 \cdot 2$ & $34 \cdot 5$ & 43.6 & 28.6 \\
\hline
\end{tabular}


Table 3. Surface temperatures estimated by multiple regression for each of the four vegetation formations and the five studied dates. The correlation coefficients and the F-ratios of the overall regression cquations are also reported.

\begin{tabular}{|c|c|c|c|c|c|}
\hline & \multicolumn{5}{|c|}{ Surface temperature. ' $C$} \\
\hline & $6 \mathrm{May}$ & + July & 21 August & 31 August & 27 September \\
\hline Shrubland & $25 \cdot 8$ & $31 \cdot 3$ & $30 \cdot 8$ & $29 \cdot 9$ & $24 \cdot 0$ \\
\hline Open woodland & 254 & $30 \cdot 7$ & $24 \cdot 6$ & $29 \cdot 0$ & $23 \cdot 3$ \\
\hline Mid-dense wordland & $24 \cdot 1$ & $2 y \cdot 7$ & $28 \cdot 8$ & $28 \cdot 1$ & $22 \cdot 6$ \\
\hline Dense woodland & $22 \cdot 6$ & $27 \cdot 5$ & $27 \cdot 1$ & $26 \cdot 6$ & $21 \cdot 3$ \\
\hline Correlation coefficients & 0.56 & 0.69 & 0.75 & 0.72 & 0.71 \\
\hline F-ratios & $21 \cdot 4$ & $43 \cdot 4$ & 62.9 & 52.9 & $47 \cdot 4$ \\
\hline
\end{tabular}

These estimated values of albedo and surface temperature are not significantly diferent $\left(t\right.$-test for paired comparison, $p<0.05$ for $a, p<0.01$ for $t_{4}$ ) from those obtained by Rambal it al. (1985) considering only pure pixels (i.e. pixels with at least 80 per cent of their area occupied by the same vegetation formation).

The seasonal courses of albedo and surface temperature as shown in tables 2 and 3 are consistent with our knowledge of vegetation phenology, seasonal evolution of air temperature and differential increase of water stress for the vegetation formations (see Rambal ('t al. 1985).

From these results. we conclude that albedos and surface temperatures of mixed pixels can be considered as linear combinations of albedos or surface temperatures of their components defined as physiognomical vegetation units. weighted by their relative areas. The quality of the tested linear relationships is better for surface temperature than for albedo (cf. table 3). This may be explained by the low thermal contrasts between vegetation formations. The underlying mechanism has been suggested by Philip (1987) studying the energy balance of a downwind evaporating surface in equilibrium with an upwind hot dry landscape. He revealed the influence of the surface resistance, the sum of the boundary layer resistance and of the canopy stomatal resistance, and showed that a high surface resistance reduced advective effects and minimized the discontinuous drop of temperature. In our case. with a $2 \mathrm{~ms}^{-1}$ (see also table 1 ) wind speed above the dense woodland or the shrubland. aerodynamic resistances are respectively about 10 and $25 \mathrm{sm}^{-1}$. The minimal canopy stomatal resistances ranges from 150 to $200 \mathrm{sm}^{-1}$ (Rambal 1989). Hence, the role of the roughness is reduced and the surface resistances come mainly from high canopy resistance: consequently, thermal contrasts are rather low. So, if we consider a large land area. composed of units of similar vegetation formation of several hectares in size, then we should be able, as a first approximation. to ignore effects of local advection at the upwind edges of the various vegetation units. to consider that interactions between them are small and treat their surface temperatures as constant throughout the studied area.

\section{References}

Badhwar. G. D. 1980. Crop emergence date determination from spectral data. Photo(jrammetric Enginetering and Remote Sinsing, 46, 369-377.

BrutsatrT. W. 1982. Evaperation into the Amosphere. Theory. History and Application (Dordrecht: Reidel). 
Byrne, G. F., BegG, J. E., Fleming, P. M., and Dunin, F. X., 1979, Remotely sensed land cover temperature and soil water status - a brief review. Remote Sensing of Environment, 8, 291-305.

GarratT, J. R., 1978, Transfer characteristics for a heterogeneous surface of large aerodynamic roughness. Quarterly Journal of the Royal Meteorological Society, 104, 491-502.

Kustas, W. P., Choudhury, B. J., Moran, M. S., Reginato, R. J., Jackson, R. D., GAY, L. W., and WEAVER, H. L., 1989, Determination of sensible heat flux over sparse canopy using thermal infrared data. Agricultural and Forest Meteorology, 44, 197-216.

Lacaze, B., Debussche, G., Khelfa, A., Mazurek, H., Rambal, S., and Caraux, D., 1984, A comparison of LANDSAT-MSS, HCMM and NOAA-AVHRR features for identifying dominant vegetation patterns in Mediterranean areas. Proceedings of the 18th International Symposium on Remote Sensing of Environment held in Paris, France, Vol. 2 (Ann Arbor: Environmental Research Institute of Michigan), pp. 787-802.

National Aeronautics and Space Administration (NASA), 1980, Heat Capacity Mapping Mission. User's Guide. Second revision (Greenbelt, Maryland: Goddard Space Flight Center).

PhILIP, J. R., 1987, Advection, evaporation, and surface resistance. Irrigation Science, 8, $101-114$

RAMBAL, S., 1990, From daily transpiration to seasonal water balance: an optimal use of water? In Time Scales of Biological Responses to Water Constraints. The Case of Mediterranean Biota, edited by J. Roy and F. Di Castri (Berlin: Springer-Verlag) (in the press).

Rambal, S., Lacaze, B., Mazurek, H., and Debussche, G., 1985, Comparison of hydrologically simulated and remotely sensed actual evapotranspiration from some Mediterranean vegetation formations. International Journal of Remote Sensing, 6, 1465-1482.

RérnIGER, P., 1981, HCMM Satellite data calibration and atmospheric corrections. Tellus Newsletter, 25, 1-16.

Ross, P. J., WILliaMs, J., and MCCOWN, R. L., 1985, Soil temperature and the energy balance of vegetative mulch in the semi-arid tropics. I. Static analysis of the radiation balance. Australian Journal of Soil Research, 23, 493-514.

Sagan, C., Toon, O. B., and Pollack, J. B., 1979, Anthropogenic albedo changes and the earth's climate. Science, 206, 1363-1368.

Salomonson, V. V., Barnes, W. L., Maymon, P. W., Montgomery, H. E., and Ostrow, M., 1989, MODIS: Advanced facility instrument for studies of the Earth as a system. I.E.E.E. Transactions on Geoscience and Remote Sensing, 27, 145-153.

Townshend, J. R. G., and Justice, C. O., 1988, Selecting the spatial resolution of satellite sensors required for global monitoring of land transformations. International Journal of Remote Sensing, 9, 187-236. 